\title{
Fluorescent amplified fragment length polymorphism (fAFLP) analyses and genetic diversity in Litopenaeus vannamei (Penaeidae)
}

\author{
Michelle Mantovani Gonçalves ${ }^{1}$, Manoel Victor Franco Lemos ${ }^{2}$, Pedro Manoel Galetti Junior ${ }^{1}$, \\ Patrícia Domingues de Freitas ${ }^{1}$ and Manuel Antonio Andrade Furtado Neto ${ }^{3}$ \\ ${ }^{1}$ Universidade Federal de São Carlos, Departamento de Genética e Evolução, São Carlos, SP, Brazil. \\ ${ }^{2}$ Universidade Estadual Paulista 'Júlio de Mesquita Filho', Departamento de Biologia Aplicada \\ à Agropecuária, Jaboticabal, SP, Brazil. \\ ${ }^{3}$ Universidade Federal do Ceará, Departamento de Engenharia de Pesca, Fortaleza, CE, Brazil.
}

\begin{abstract}
The Pacific white shrimp, Litopenaeus vannamei (Penaeidae), represents about $95 \%$ of all Brazilian shrimp production. The Brazilian L. vannamei foundation broodstock was made up of specimens collected from different American Pacific sites, but little information was collected on the genetic structure of the broodstock. We used the fluorescence amplified fragment length polymorphism (fAFLP) method to study the genetic diversity of $L$. vannamei broodstock lines 03CMF1 and 03CBF1 originally produced by breeder-shrimps imported mainly from Panama and Ecuador, although wild individuals from other localities may also have been used in producing these two lines. Our results showed a total of 93 polymorphic bands ranging from 50 to $500 \mathrm{bp}$, the mean Nei's genetic diversity calculated for the total sample was $13.4 \%$ and identity and genetic distance analyses indicated high genetic homogeneity within and between both the broodstock lineages studied which suggests that they had similar genetic structure. These results may represent an important tool for the appropriate management of $L$. vannamei broodstocks.
\end{abstract}

Key words: fAFLP, genetic diversity, Litopenaeus vannamei, Penaeidae, shrimp.

Received: June 2, 2004; Accepted: December 8, 2004.

The Pacific white shrimp, Litopenaeus vannamei (Penaeidae), represents about $95 \%$ of all Brazilian shrimp production which has risen from 40,000 ton in 2001 to approximately 80,000 ton in 2003 , representing nearly $5.3 \%$ of world production and making Brazil among the top seven producers (Rocha and Rodrigues, 2003).

The L. vannamei foundation broodstock was created from specimens collected from different American Pacific sites and little is known on their genetic structure. Genetic tools consisting of molecular and genetic manipulation technologies have been widely used to improve the aquaculture of several species (Dall et al., 1990, Sagi and Cohen, 1990, Xiang et al., 1992), with polymerase chain reaction (PCR) technology having been particularly useful in identifying several molecular markers which have been extremely useful in shrimp aquaculture where they have been used for the identification of populations and genetic diversity analyses (Sunden and Davis, 1991; Garcia et al., 1996).

Send correspondence to Michelle Mantovani Gonçalves. Universidade Federal de São Carlos, Caixa Postal 676, 13575-905 São Carlos, SP, Brazil. E-mail: mmantovanig@ hotmail.com.
The fluorescence amplified fragment length polymorphism (fAFLP) assay is based on the amplification of restriction fragments from genomic DNA and the analysis of the amplified products using polyacrylamide gel electrophoresis, differing from conventional AFLP only by the use of primers labeled with a fluorochrome instead of the radioactive phosphorus $\left[\gamma^{32} \mathrm{P}\right]$ used in the standard method. Conventional AFLP is particularly useful for genomic mapping and genetic fingerprinting and may be used to calculate genetic distances between individual members of a population (Vos et al., 1995), AFLP markers having already been used for constructing linkage maps, establishing pedigrees and identifying quantitative trait loci (QTL) in shrimp species such as Marsupenaeus japonicus (Moore et al., 1999; Li et al., 2003) and Penaeus monodon (Wilson et al., 2002). Garcia et al. (1994) used allozymes, random amplified polymorphic DNA (RAPD) and restriction fragment length polymorphism (RFLP) analyses to study the genetic diversity of cultured L. vannamei and detected greater genetic variation using RFLP as compared to RAPD, although RAPD has been used to assess genetic variation in six captive shrimp families (Garcia and Benzie, 1995) and in wild 
populations of P. monodon (Tassanakajon et al., 1997), and in Litopenaeus stylirostris (Aubert and Lightner, 2000).

Genetic studies in captive Brazilian L. vannamei populations have only recently been carried out, Freitas and Galetti Jr. (2002) having used PCR-based variable number tandem repeat (VNTR) core sequence analysis to detect significant genetic differences between two reared lineages, while Freitas (2003) used RAPD analysis to study the genetic diversity of 15 broodstock lines owned by seven Brazilian hatcheries and Francisco (2003) applied mitochondrial DNA analyses to reveal low genetic distances among four reared broodstocks.

The study presented in this paper was carried out in order to standardize a fAFLP protocol for studying shrimp DNA, and to evaluate the genetic diversity within and between two L. vannamei broodstocks reared in northeastern Brazil.

Samples were obtained from broodstock lines 03CMF1 (16 specimens) and 03CBF1 (14 specimens) (both lines owned by Compescal hatchery industry, Aracati, Ceará, Brazil) which had originally been formed from by breeder-shrimps (about 100 breeder couples for each line) imported mainly from Panama and Ecuador, although wild specimens from other localities may also have been incorporated into the stocks.

Total genomic DNA samples were obtained from the pleopod muscles of each specimen using a phenol/chloroform/isoamyl 25:24:1 protocol (Sambrook et al., 1989). The fAFLP reactions were performed using to the Applied Biosystems AFLP Plant Mapping Protocol Kit (Anon, 1997) with the genomic DNA (500 ng) being digested with EcoRI and MseI before ligation of restriction site-specific adaptors. Pre-selective amplification was carried out using adaptor-specific primers with a single selective base on each primer, two sets of site-specific MseI and Eco RI primers (ACG-CAA and AGG-CAG) being used for the selective amplification reaction. Each sample was loaded onto a 5\% Long-Ranger denaturing gel which was run in an ABI PRISM $^{\text {TM }} 377$ DNA Sequencer (PE-Applied Biosystems) for $3 \mathrm{~h}$ at 2,500 V. The electrophoresis images obtained from each run were analyzed using the GENESCAN program version 3.1 (Applied Biosystems). The Genotyper program version 2.5 (Applied Biosystems) was used to verify the presence (coded as 1 ) or absence (coded as 0 ) of polymorphic bands in the electropherograms and produce a binary matrix and the POPGENE program version 1.31 (Yeh et al., 1999) was used to calculate Nei's genetic diversity (Nei, 1973), genetic distance (Nei, 1972) and identity (Nei, 1978).

We found that the fAFLP method was efficient at analyzing genetic diversity in L. vannamei broodstocks. The banding-patterns obtained with the two primer pairs for the 30 DNA samples generated a total of 93 polymorphic bands with sizes ranging from 50 to $500 \mathrm{bp}$. The fluorescent ACG-CAA primer pair generated 48 polymorphic bands, while the AGG-CAG primer pair generated 45 polymorphic bands.

Nei's genetic identity value between both broodstock lines was 0.9947 and Nei's genetic distance was 0.0053 , suggesting that the genetic structure of the two lines are very similar. The historical data for the two lines show that the majority of the founder-shrimps came from Panama and Ecuador, the genetic homogeneity observed by us possibly being due to this common origin. Both broodstocks were $F_{1}$ lines (separated from each other by only one generation), so if genetic drift occurred during the foundation of the $F_{1}$ lines it may have had quite similar effects on the genetic structure of both lines. Mitochondrial DNA (mtDNA) analysis has also shown low genetic divergence and an inferred common origin for other L. vannamei broodstock lines (Francisco, 2003).

It is well-known that molecular analyses are very important in order to conduct an adequate monitoring of captive stocks and to establish profitable genetic improvement programs (Sunden and Davis, 1991). Reduction in genetic diversity may increase susceptibility to disease and other selective factors which can lead to lower populations (Xu et al., 2001). Genetic deterioration of cultured shrimp populations has been related to inbreeding effects in succeeding generations and genetic drift. Sbordoni et al. (1986) analyzed the genetic variability of Penaeus japonicus cultured for six generations and found a continuous reduction in the level of genetic variability with each succeeding generation which they thought was a consequence of severe genetic drift and inbreeding. Freitas (2003) also reported such effects in L. vannamei where RAPD analyses revealed significant loss in genetic variation during five inbred generations. It has been stated (Waldman, 1999) that the increase in intrapopulational genetic similarity during succeeding generations results in a large interpopulational genetic distance, and it is also known that genetic variation can be restored by using separated inbred lines for cross-breeding (Freitas and Galetti Jr., 2002; Sánchez et al., 2003).

When both broodstock lines were grouped together we found that the overall mean Nei's genetic diversity (13.4\%) was still not high (Table 1) as compared to the levels detected in an AFLP study of wild L. vannamei populations by Travis (2002) who found higher levels of genetic variation than those found in our studies. Although effects related to the relatively small size of our sample (100 couples) should be borne in mind, we believe that the apparent reduction in genetic variation observed by us was probably due to genetic drift during broodstock foundation.

Our results contribute data on the study of genetic variation in captive populations of shrimps using fAFLP and show that both the broodstock lines studied have a very similar genetic structure, the assessment of genetic structure representing an important tool for designing more appropriate management programs for $L$. vannamei broodstocks. 
Table 1 - Nei's genetic diversity values for the total Litopenaeus vannamei sample ( $\mathrm{n}=16$ for broodstock line $03 \mathrm{CMF} 1$; $\mathrm{n}=14$ for line $03 \mathrm{CBF} 1)$ and the overall sample mean $(n=30)$ and the overall mean considering both sets of primers.

\begin{tabular}{|c|c|c|c|}
\hline $\begin{array}{l}\text { Fragments from } \\
\text { ACG-CAA primer }\end{array}$ & $\begin{array}{l}\text { Nei's genetic } \\
\text { diversity }\end{array}$ & $\begin{array}{l}\text { Fragments from } \\
\text { AGG-CAG primer }\end{array}$ & $\begin{array}{c}\text { Nei's genetic } \\
\text { diversity }\end{array}$ \\
\hline 1a & 0.1286 & $1 b$ & 0.0333 \\
\hline $2 \mathrm{a}$ & 0.0655 & $2 b$ & 0.1286 \\
\hline $3 a$ & 0.3032 & $3 b$ & 0.0976 \\
\hline $4 a$ & 0.1295 & $4 b$ & 0.2527 \\
\hline $5 a$ & 0.3296 & $5 b$ & 0.3296 \\
\hline $6 a$ & 0.3020 & $6 \mathrm{~b}$ & 0.1596 \\
\hline $7 \mathrm{a}$ & 0.0655 & $7 b$ & 0.4142 \\
\hline $8 a$ & 0.1295 & $8 b$ & 0.0978 \\
\hline $9 a$ & 0.1327 & $9 b$ & 0.3020 \\
\hline $10 \mathrm{a}$ & 0.2185 & $10 \mathrm{~b}$ & 0.2741 \\
\hline $11 \mathrm{a}$ & 0.1889 & $11 \mathrm{~b}$ & 0.2775 \\
\hline $12 \mathrm{a}$ & 0.0333 & $12 b$ & 0.2998 \\
\hline $13 a$ & 0.1625 & $13 b$ & 0.0978 \\
\hline $14 \mathrm{a}$ & 0.0655 & $14 b$ & 0.3002 \\
\hline $15 \mathrm{a}$ & 0.2481 & $15 b$ & 0.2998 \\
\hline $16 a$ & 0.2467 & $16 b$ & 0.1286 \\
\hline $17 \mathrm{a}$ & 0.1889 & $17 b$ & 0.3494 \\
\hline $18 \mathrm{a}$ & 0.2775 & $18 \mathrm{~b}$ & 0.2775 \\
\hline $19 a$ & 0.1286 & $19 b$ & 0.2481 \\
\hline $20 \mathrm{a}$ & 0.1295 & $20 \mathrm{~b}$ & 0.0655 \\
\hline $21 \mathrm{a}$ & 0.1889 & $21 b$ & 0.0655 \\
\hline $22 \mathrm{a}$ & 0.0655 & $22 b$ & 0.0668 \\
\hline $23 a$ & 0.0333 & $23 b$ & 0.2775 \\
\hline $24 a$ & 0.2734 & $24 b$ & 0.0978 \\
\hline $25 \mathrm{a}$ & 0.0333 & $25 b$ & 0.1341 \\
\hline
\end{tabular}

\begin{tabular}{|c|c|c|c|}
\hline $\begin{array}{l}\text { Fragments from } \\
\text { ACG-CAA primer }\end{array}$ & $\begin{array}{l}\text { Nei's genetic } \\
\text { diversity }\end{array}$ & $\begin{array}{l}\text { Fragments from } \\
\text { AGG-CAG primer }\end{array}$ & $\begin{array}{c}\text { Nei's genetic } \\
\text { diversity }\end{array}$ \\
\hline $26 \mathrm{a}$ & 0.0333 & $26 b$ & 0.0655 \\
\hline $27 \mathrm{a}$ & 0.0333 & $27 b$ & 0.2217 \\
\hline $28 \mathrm{a}$ & 0.0334 & $28 b$ & 0.0976 \\
\hline $29 \mathrm{a}$ & 0.0334 & $29 b$ & 0.0655 \\
\hline $30 \mathrm{a}$ & 0.0333 & $30 \mathrm{~b}$ & 0.0333 \\
\hline $31 \mathrm{a}$ & 0.2461 & $31 b$ & 0.0655 \\
\hline $32 \mathrm{a}$ & 0.0334 & $32 b$ & 0.0333 \\
\hline $33 a$ & 0.0333 & $33 b$ & 0.1301 \\
\hline $34 \mathrm{a}$ & 0.0655 & $34 b$ & 0.0333 \\
\hline $35 \mathrm{a}$ & 0.0333 & $35 b$ & 0.0333 \\
\hline $36 a$ & 0.0333 & $36 b$ & 0.1889 \\
\hline $37 \mathrm{a}$ & 0.0334 & $37 b$ & 0.0333 \\
\hline $38 \mathrm{a}$ & 0.0655 & $38 b$ & 0.0333 \\
\hline $39 a$ & 0.0333 & $39 b$ & 0.2185 \\
\hline $40 \mathrm{a}$ & 0.0334 & $40 \mathrm{~b}$ & 0.0333 \\
\hline $41 \mathrm{a}$ & 0.0333 & $41 b$ & 0.0333 \\
\hline $42 \mathrm{a}$ & 0.2775 & $42 b$ & 0.0334 \\
\hline $43 a$ & 0.1906 & $43 b$ & 0.0333 \\
\hline $44 a$ & 0.0655 & $44 b$ & 0.0334 \\
\hline $45 \mathrm{a}$ & 0.2481 & $45 b$ & 0.0668 \\
\hline $46 a$ & 0.0978 & & \\
\hline $47 \mathrm{a}$ & 0.0976 & & \\
\hline $48 \mathrm{a}$ & 0.0333 & & \\
\hline Overall mean & & & 0.1339 \\
\hline
\end{tabular}

\section{Acknowledgments}

The authors thank the following: Laboratório de Larvicultura Compescal (Aracati, Ceará, Brazil) for providing the shrimp samples; Laboratório de Bioquímica de Microrganismos e Plantas, Departamento de Tecnologia da UNESP/Jaboticabal-SP for laboratory facilities; and Fundação Cearense de Apoio ao Desenvolvimento Científico e Tecnológico (FUNCAP) and the Conselho Nacional de Desenvolvimento Científico e Tecnológico (CNPq) for financial support.

\section{References}

Anon, Applied Biosystems (1997) AFLP Plant Mapping Protocol, California, USA, $45 \mathrm{pp}$

Aubert $\mathrm{H}$ and Lightner DV (2000) Identification of genetic populations of the Pacific blue shrimp Penaeus stylirostris of the Gulf of California, Mexico. Mar Biol 137:875-885.

Dall W, Hill J, Rothlisberg PC and Staples DJ (1990) The biology of Penaeidae. In: Blaxter JHS and Southward AJ (eds) Advances in Marine Biology. v. 27. Academic Press, New York, $489 \mathrm{pp}$.

Francisco AK (2003) Relações genéticas entre plantéis de reprodutores do camarão marinho Litopenaeus vannamei, através do seqüenciamento dos genes RNAr $16 \mathrm{~S}$ e COI do DNAmt. MSc Thesis, Universidade Federal de São Carlos, São Carlos, 68 pp.

Freitas PD (2003) Estudos de diversidade genética em estoques reprodutores de camarões Litopenaeus vannamei cultivados no Brasil. Doctoral Thesis, Universidade Federal de São Carlos, São Carlos, 132 pp.

Freitas PD and Galetti Jr PM (2002) PCR-based VNTR core sequence analysis inferring on genetic diversity of cultured prawn Litopenaeus vannamei. Genet Mol Biol 25:431-434.

Garcia DJ, Faggart MA, Rhoades L, Wyban JA, Carr WH, Sweeney JN, Ebert KM and Alcivar-Warren A (1994) Genetic diversity of cultured Penaeus vannamei shrimp using three molecular genetics techniques. Mol Marine Biol Biotechnol 3:270-280.

Garcia DK and Benzie JAH (1995) RAPD markers of potential use in penaeid prawn (Penaeus monodon) breeding programs. Aquaculture 130:137-144.

Garcia DK, Dhar AK and Alcivar-Warren A (1996) Molecular analysis of a RAPD marker (B20) reveals two micro- 
satellites and differential mRNA expression in Penaeus vannamei. Mol Marine Biol Biotechnol 5:71-83.

Li Y, Byrne K, Emmanuela M, Whan V, Moore S, Keys S, Crocos P, Preston N and Lehnert S (2003) Genetic mapping of the Kuruma Penaeus japonicus using AFLP markers. Aquaculture 219:143-156.

Moore SS, Whan V, Davis GP, Byrne K, Hetzel DJS and Preston $\mathrm{N}$ (1999) The development and application of genetic markers for the kuruma prawn Penaeus japonicus. Aquaculture 173:19-32.

Nei M (1972) Genetic distance between population. Am Nat 106:283-292.

Nei M (1973) The theory and estimation of genetic distance. In: Morton NE (ed) Genetic Structure of Populations. University of Hawaii, Honolulu, pp 45-54.

Nei M (1978) Estimation of average heterozygosity and genetic distance from a small number of individuals. Genetics 89:583-590.

Rocha IP and Rodrigues J (2003) A Carcinicultura brasileira em 2002. Rev da ABCC 5:30-45.

Sagi A and Cohen D (1990) Growth, maturation and progeny of sex reversed Macrobrachium rosenbergii males. World Aquac 21:87-90.

Sambrook J, Fritsch EF and Maniatis T (1989) Molecular Cloning: A Laboratory Manual. 2nd edition. Cold Spring Harbor Laboratory Press, Cold Spring Harbor.

Sánchez L, Bijma P and Woolliams JA (2003) Minimizing inbreeding by managing genetic contributions across generations. Genetics 164:1589-1595.

Sbordoni V, De Matheis E, Cobolli-Sbordoni M, La Rosa G and Mottlcaccia M (1986) Bottleneck effects and the depression of genetic variability in hatchery stocks of Penaeus japonicus (Crustacea, Decapoda). Aquaculture 57:239-251.

Sunden SLF and Davis SK (1991) Evaluation of genetic variation in a domestic population of Penaeus vannamei (Bonne): A comparison whit three natural population. Aquaculture 151:131-142.

Tassanakajon A, Siriporn P and Rimphanitchayakit V (1997) Random amplified polymorphic DNA (RAPD) markers for determination of genetic variation in wild populations of the black tiger (Penaeus monodon) in Thailand. Mol Marine Biol Biotechnol 6:110-115.

Travis SE (2002) Hurricane Mitch: Population genetic structure of Pacific white shrimp from the Gulf of Fonseca, Honduras. USGS Open File Report 03-174, 30 pp.

Vos P, Hogers R, Bleeker M, Reijans M, Lee T, Vande Lee, Hornes M, Frijters A, Pot J, Peleman J, Kuiper M and Zabeu M (1995) AFLP: A new technique for DNA fingerprinting. Nucleic Acids Res 23:4407-4414.

Waldman JP (1999) The importance of comparative studies in stock analysis. Fish Res 43:237-246.

Wilson K, Li Y, Whan V, Leghnert S, Byrne K, Moore S, Pongsomboon S, Tassanakajon A, Rosenberg G, Ballment E, Fayazi Z, Swan J, Kenway M and Benzie J (2002) Genetic mapping of the black tiger shrimp Penaeus monodon with amplified fragment length polymorphism. Aquaculture 204:297-309.

Xiang JH, Zhou LH, Liu RY, Zhu JZ, Li XH and Liu XD (1992) Induction of the tetraploids of the chinese shrimp, Penaeus chinensis. In: Asia Pacific Conference on Agricultural Biotechnology, Beijing, 20-24. China Science and Technology Press, Beijing, pp 841-846.

Xu Z, Primavera JH, De Le Pene LD, Pettit P, Belak J and Alcivar-Warren A (2001) Genetic diversity of wild and cultured Black tiger Shrimp (Penaeus monodon) in the Philippines using microsatellites. Aquaculture 199:13-40.

Yeh F, Yang R and Boyle T (1999) Microsoft windows-based freeware for population genetic analysis, Popgene version 1.31. available at: http://www.ualberta.ca/ fyeh/download. htm.

Associate Editor: Sérgio Furtado dos Reis 